\title{
PENGARUH MODEL PEMBELAJARAN DISCOVERY LEARNING TERHADAP HASIL BELAJAR SISWA KELAS XI SEMESTER GENAP PADA MATERI POKOK FLUIDA DINAMIS DI SMA N 1 STABAT T.P 2014/2015
}

\author{
Ayu Syahputri dan Derlina \\ Jurusan Fisika FMIPA Universitas Negeri Medan \\ Jalan Willem Iskandar Pasar V Medan \\ ayusyahputri02@gmail.com
}

\begin{abstract}
ABSTRAK
Penelitian ini bertujuan untuk mengetahui pengaruh model pembelajaran discovery learning terhadap hasil belajar siswa kelas XI semester genap pada materi pokok fluida dinamisdi SMA N1 Stabat T.P. 2014/2015.Jenis penelitian ini adalah quasi eksperimen.Pengambilan sampel dilakukan dengan cara cluster random sampling. Dari data penelitian diperoleh nilai rata-rata pretes kelas eksperimen adalah 48,33. Pada uji normalitas dan homogenitas kedua kelas berdistribusi normal dan homogen. Hasil uji t pretes $\mathrm{H}_{0}$ diterima, berarti kedua kelas memiliki kemampuan awal yang sama.Setelah diberikan perlakuan yang berbeda, kelas eksperimen dengan model pembelajaran discovery learning dan kelas kontrol dengan model pembelajaran konvensional, diperoleh hasil postes dengan hasil rata-rata kelas eksperimen 78,33. Pada uji normalitas dan homogenitas kedua kelas berdistribusi normal dan homogen.Hasil uji t postesH $\mathrm{H}_{\mathrm{a}}$ diterima. Dengan demikian, diperoleh bahwa hasil belajar siswa menggunakan model pembelajaran discovery learning lebih baik daripada hasil belajar siswa dengan menggunakan model pembelajaran konvensional pada materi pokok fluida dinamis kelas XI semester genap di SMA N 1 Stabat T.P $2014 / 2015$.
\end{abstract}

Kata kunci : discovery learning, konvensional, hasil belajar

\begin{abstract}
This study aims to determine the effect of discovery learning model learning on learning outcomes of students of class XI semester in the subject matter of dynamic fluid in SMA N 1 Stabat TP 2014/2015. This research is a quasi experimental. Sampling was done by cluster random sampling. From the research data obtained by the average value of the experimental class pretest was 48.33. On normality and homogeneity test both normal and homogeneous distribution classes. H0 t test results pretest is received, meaning both classes have the same initial ability. After being given a different treatment, experimental class discovery learning model learning and classroom control with conventional learning models, post-test results obtained with an average yield of 78.33 experimental class. On normality and homogeneity test both normal and
\end{abstract}


homogeneous distribution classes. T test results postes $\mathrm{Ha}$ accepted. Thus, it was found that the results of student learning using learning discovery learning model is better than the results of student learning using the conventional learning model in the subject matter of dynamic fluid in the second semester of class XI SMA N 1 Stabat TP 2014/2015.

Keywords: discovery learning, conventional, learning outcomes

\section{PENDAHULUAN}

Pada Kurikulum 2013, siswa dituntut berperan aktif dalam proses pembelajaran.

Kegiatan pembelajaran dalam Kurikulum 2013 diarahkan untuk memberdayakan semua potensi yang dimiliki peserta didik agar mereka dapat memiliki kompetensi yang diharapkan. Kebijakan pengembangan Kurikulum 2013 diharapkan mampu menghasilkan insan Indonesia yang produktif, kreatif, inovatif, dan afektif melalui penguatan sikap, keterampilan, dan pengetahuan yang terintegrasi. Implementasi Kurikulum 2013 dalam pembelajaran dengan pendekatan saintifik adalah proses pembelajaran yang dirancang sedemikian rupa agar peserta didik secara aktif mengkonstruk konsep, hukum atau prinsip melalui tahapan - tahapan mengamati (untuk mengidentifikasi atau menemukan masalah), merumuskan masalah, mengajukan atau merumuskan hipotesis, mengumpulkan data dengan berbagai teknik, menganalisis data, menarik kesimpulan dan mengomunikasikan konsep, hukum atau prinsip yang "ditemukan" (Hosnan, 2014: 34).

Berdasarkan hasil pengamatan yang telah dilakukan peneliti selama mengikuti program pengalaman lapangan terpadu (PPLT) dan observasi yang dilakukan sebelum menentukan judul proposal penelitian menunjukkan bahwa kegiatan pembelajaran fisika belum sesuai dengan Kurikulum 2013 yang menuntut siswa berperan aktif. Kenyataan yang terjadi siswa masih pasif dalam proses pembelajaran karena pembelajaran masih berpusat pada guru. Guru lebih menekankan siswa untuk menghafal rumus fisika agar mampu menyelesaikan soal soal yang diberikan. Siswa hanya menyerap informasi yang diberikan oleh guru sehingga siswa kurang tertarik dalam pembelajaran fisika dan tidak dapat mengembangkan pengetahuan yang ia miliki. Guru tidak melatih siswa untuk mampu memecahkan masalah dan mencari pengalaman dengan melakukan percobaan/belajar mandiri yang memungkinkan mereka untuk menemukan pengetahuan baru. Hal ini menyebabkan siswa tidak memiliki kemampuan untuk mengeksplorasi dan memecahkan masalah. Sehingga siswa tidak memiliki kesempatan untuk mengembangkan pengetahuannya dan menemukan pengetahuan yang baru melalui proses pembelajaran. Dengan begitu siswa tidak tertarik dan malas mengikuti pelajaran fisika sehingga pengetahuan mereka terkait pelajaran fisika sangat kurang dan berimbas pada hasil belajar mereka yang masih rendah.

Berkaitan dengan permasalahan yang terjadi pada pembelajaran fisika di sekolah, maka guru harus menggunakan model pembelajaran yang bervariasi agar siswa lebih tertarik dan aktif dalam 
mengikuti proses pembelajaran di sekolah sehingga hasil yang didapat siswa tidak sebatas untuk mencapai target dan tujuan pembelajaran saja, terlebih siswa akan mendapatkan pembelajaran yang lebih bermakna dan menemukan sesuatu yang baru.

Salah satu cara yang dapat digunakan untuk mengatasi masalah meningkatkan keaktifan siswa adalah dengan menggunakan model pembelajaran yang berpusat pada siswa (student center learning). Dengan aktifnya siswa dalam proses pembelajaran maka diharapkan pembelajaran lebih bermakna, sehingga siswa jadi lebih merasa terlibat dan termotivasi sendiri untuk terus belajar. Model pembelajaran yang cocok untuk mengatasi masalah terkait kemampuan siswa dalam mengeksplorasi dan memecahkan masalah sehingga siswa menemukan pengetahuan baru adalah model pembelajaran discovery learning. Model pembelajaran discovery learning adalah model yang melatih siswa untuk mengeksplorasi dan memecahkan masalah melalui cara menghimpun informasi, membandingkan, mengkategorikan, menganalisis, mengintegrasikan, mereorganisasikan bahan serta membuat kesimpulan - kesimpulan. Model pembelajaran discovery learning ini terdiri dari rangkaian tahap - tahap kegiatan yang diorganisasikan sedemikian rupa membentuk suatu kesinambungan sehingga pembelajar dapat menguasai kompetensi - kompetensi yang harus dicapai dalam pembelajaran dengan jalan berperan aktif. Selain itu, model pembelajaran discovery learningcocok untuk mengembangkan aspek proses dan sikap dalam kegiatan pembelajaran karena pada model pembelajaran discovery learning siswa dituntut untuk menemukan suatu konsep. Untuk menemukan suatu konsep siswa akan mengalami proses dan menunjukkan sikapnya sehingga karakteristik pelajaran fisika akan terlihat.

Berdasarkan uraian masalah di atas, maka penulis tertarik untuk melakukan penelitian dengan judul : "Pengaruh Model Pembelajaran Discovery Learning Terhadap Hasil Belajar Siswa Kelas XI Semester Genap Pada Materi Pokok Fluida Dinamis Di SMA N 1 Stabat T.P. 2014/2015."

\section{METODE PENELITIAN}

Penelitian ini merupakan penelitian quasi eksperimen. Penelitian dilakukan di SMA N 1 Stabat. Populasi dalam penelitian ini adalah seluruh siswa kelas XI SMA N 1 Stabat. Sampel penelitian ini terdiri dari dua kelas yaitu kelas eksperimen dan kelas kontrol yang diambil dengan teknik cluster random sampling. Variabel bebas dalam penelitian ini adalah pembelajaran dengan menggunakan model pembelajaran discovery learning dan variabel terikat dalam penelitian ini adalah hasil belajar siswa pada materi pokok fluida dinamis. Pengumpulan data dilakukan melalui tes pilihan berganda untuk mengetahui kemampuan kognitif siswa.

\section{HASIL DAN PEMBAHASAN Hasil Penelitian}

Sebelum diberikan perlakuan kedua kelas sampel terlebih dahulu diberikan pretes untuk mengetahui kemampuan awal siswa. Data hasil pretes yang diperoleh dari kedua kelas sampel dapat dilihat pada Tabel 1 . 
Tabel 1. Data pretes pada kelas kontrol

Kelas Eksperimen

Kelas Kontrol

\begin{tabular}{|c|c|c|c|c|c|c|c|}
\hline Nilai & Frekuensi & $\begin{array}{l}\text { Rata- } \\
\text { rata }\end{array}$ & $\begin{array}{l}\text { Standar } \\
\text { Deviasi }\end{array}$ & Nilai & Frekuensi & $\begin{array}{l}\text { Rata- } \\
\text { rata }\end{array}$ & $\begin{array}{l}\text { Standar } \\
\text { Deviasi }\end{array}$ \\
\hline 30 & 3 & \multirow{9}{*}{48,33} & \multirow{9}{*}{10,85} & 30 & 4 & \multirow{9}{*}{47} & \multirow{9}{*}{11,49} \\
\hline 35 & 4 & & & 35 & 5 & & \\
\hline 40 & 2 & & & 40 & 2 & & \\
\hline 45 & 4 & & & 45 & 3 & & \\
\hline 50 & 4 & & & 50 & 5 & & \\
\hline 55 & 6 & & & 55 & 5 & & \\
\hline 60 & 5 & & & 60 & 3 & & \\
\hline 65 & 2 & & & 65 & 3 & & \\
\hline & $=30$ & & & \multicolumn{2}{|c|}{$\sum=30$} & & \\
\hline
\end{tabular}

Setelah memperoleh data hasil pretessiswa dari kelas eksperimen dan kelas kontrol, maka dilakukan terlebih dahulu pengujian analisa data berupa uji normalitas, uji homogenitas dan uji t dua pihak. Pada uji normalitas dan homogenitas kedua kelas berdistribusi normal dan homogen. Hasil uji $\mathrm{t}$ pretes diperoleh $\mathrm{t}_{\text {hitung }}<$ $t_{\text {tabel }}=0,59<1,988$ maka $\mathrm{H}_{0}$ diterima, berarti kedua kelas memiliki kemampuan awal yang sama.Kemudian kedua kelas sampel diberikan postes untuk mengetahui kemampuan yang dimiliki siswa setelah diberikan perlakuan yang berbeda, kelas eksperimen dengan model pembelajaran discovery learning dan kelas kontrol dengan model pembelajaran konvensional. Data hasil postes yang diperoleh dari kedua kelas sampel dapat dilihat pada Tabel 2 .

Tabel 2. Data postes kelas eksperimen dan kelas kontrol

Kelas Eksperimen Kelas Kontrol

\begin{tabular}{|c|c|c|c|c|c|c|c|}
\hline Nilai & Frekuensi & $\begin{array}{l}\text { Rata- } \\
\text { rata }\end{array}$ & $\begin{array}{c}\text { Standar } \\
\text { Deviasi }\end{array}$ & Nilai & Frekuensi & $\begin{array}{l}\text { Rata- } \\
\text { rata }\end{array}$ & $\begin{array}{c}\text { Standar } \\
\text { Deviasi }\end{array}$ \\
\hline 60 & 1 & \multirow{9}{*}{78,33} & \multirow{9}{*}{8,24} & 55 & 2 & \multirow{9}{*}{74,17} & \multirow{9}{*}{10,09} \\
\hline 65 & 3 & & & 60 & 4 & & \\
\hline 70 & 2 & & & 65 & 1 & & \\
\hline 75 & 7 & & & 70 & 5 & & \\
\hline 80 & 7 & & & 75 & 5 & & \\
\hline 85 & 7 & & & 80 & 5 & & \\
\hline 90 & 2 & & & 85 & 7 & & \\
\hline 95 & 1 & & & 90 & 1 & & \\
\hline & $=30$ & & & & $=30$ & & \\
\hline
\end{tabular}

Setelah memperoleh data hasil postessiswa dari kelas eksperimen dan kelas kontrol, maka dilakukan pengujian analisa data berupa uji normalitas, uji homogenitas dan uji t satu pihak. Pada uji normalitas dan homogenitas berdistribusi kedua normal kelas dan
homogen.Hasil uji $t$ postes diperoleht $t_{\text {hitung }}>t_{\text {tabel }}=2,26>1,988$ sehinggaH $_{a}$ diterima. Dengan demikian, diperoleh bahwa hasil belajar siswa menggunakan model pembelajaran discovery learning lebih baik daripada hasil belajar siswa dengan menggunakan model 
pembelajaran konvensional pada materi pokok fluida dinamis kelas XI semester genap di SMA N 1 Stabat T.P 2014/2015.

\section{Pembahasan}

Hasil penelitian yang diperoleh menunjukkan bahwa ada perbedaan hasil belajar siswa yang menggunakan model pembelajaran discovery learning dengan model pembelajaran konvensional. Hal ini dapat dilihat dari hasil postes pada kelas eksperimen lebih baik daripada hasil postes pada kelas kontrol.Demikian halnya dengan (Herdian, 2010), (Putrayasa, 2014) juga menyatakan bahwa hasil belajar siswa yang menggunakan model pembelajaran discovery learning lebih baik daripada hasil belajar siswa yang menggunakan model pembelajaran konvensional. Hasil belajar siswa dengan menggunakan model pembelajaran discovery learning lebih baik disebabkan karena model pembelajaran discovery learning menuntun siswa berperan aktif dan memberikan kesempatan kepada siswa untuk mengeksplorasi sendiri pengetahuannya sehingga siswa menemukan suatu pengetahuan dalam proses pembelajaran.

Tuntutan siswa untuk berperan aktif mengakibatkan siswa harus terlibat langsung dalam proses pembelajaran.Dengan keterlibatan siswa secara langsung dalam proses pembelajaran, maka proses pembelajaran menjadi tidak membosankan sehingga siswa akan lebih tertarik untuk mengikuti pelajaran di dalam kelas.

Model pembelajaran discovery learning dapat menumbuhkan dan membangkitkan motivasi belajar siswa. Motivasi belajar siswa muncul disebabkan karena siswa terlibat langsung dalam proses pembelajaran sehingga siswa lebih tertarik dalam mengikuti proses pembelajaran di dalam kelas. Ketertarikan siswa dalam mengikuti proses pembelajaran di dalam kelas mengakibatkan siswa lebih semangat untuk mengikuti pelajaran. Hasil penelitian ini sejalan dengan (Jacobsen, 2009) yang menyatakan bahwa model pembelajaran discovery learning, guru akan lebih sedikit dalan menjelaskan sehingga siswa lebih aktif dalam pembelajaran secara kognitif, mendorong pembelajaaran dan motivasi.

Selain itu, model pembelajaran discovery learning juga dapat memunculkan sikap keilmiahan siswa, misalnya sikap objektif, rasa ingin tahu, dan berpikir kritis. Terpacunya rasa ingin tahu siswa menyebabkan siswa akan menjadi lebih bersemangat untuk belajar dan menambah pengetahuannya. Rasa ingin tahu siswa akan memberikan motivasi bagi siswa untuk mencari tahu jawaban atas pertanyaan pertanyaan atau masalah - masalah yang muncul dan dihadapinya. Hubungan antara rasa ingin tahu dan ingin menyelesaikan masalah searah dengan motivasi belajar. Artinya semakin besar rasa ingin tahu siswa dan ingin menemukan penyelesaian dari masalah, maka semakin besar pula motivasi belajar yang dimiliki siswa. Hal ini terbukti dari siswa yang mampu dan ingin mencari tahu untuk menemukan penyelesaian suatu masalah yang dimunculkan di dalam kelas. Senada dengan (Slavin, 2011) menyatakan bahwa keunggulan model discovery learning yaitu membangkitkan rasa ingin tahu siswa dan memotivasi mereka untuk terus bekerja dalam 
menemukan jawaban, siswa juga mempelajari kemampuan penyelesaian soal dan pemikiran kritis secara mandiri karena mereka harus menganalisis dan memanipulasi data. Jadi, model pembelajaran discovery learning dapat memberikan ruang bagi siswa untuk mengeksplorasi pengetahuannya.

Sesuai dengan karakteristik model pembelajaran discovery learning siswa dituntut untuk menemukan suatu konsep atau pengetahuan yang sebelumnya tidak diketahuinya. Untuk menemukan suatu konsep atau pengetahuan yang sebelumnya tidak diketahui, siswa diberikan kesempatan untuk mengeksplorasi sendiri pengetahuannya. Siswa melakukan eksplorasi dengan melakukan percobaan secara berkelompok. Ketika melakukan percobaan, siswa akan berusaha untuk menyelesaikan tugas yang diberikan dan memecahkan permasalahan yang terjadi. Sehingga kemampuan siswa dalam memecahkan masalah dengan menggunakan model pembelajaran discovery learning lebih baik daripada kemampuan siswa dalam memecahkan masalah dengan menggunakan model pembelajaran konvensional. Hal ini disebabkan karena pada saat proses menemukan akan membuat siswa lebih baik pemahamannya terhadap masalah yang dihadapi sehingga membuat siswa lebih baik dalam memecahkan masalah fisika.

Penelitian ini juga didukung oleh (Rahman, 2010) menyatakan discovery learningdapat meningkatkan pemahaman konsep siswa. Siswa mengkaitkan kesamaan konsep yang telah mereka pelajari untuk menemukan konsep baru tentang materi yang sedang dipelajari. Siswa yang belajar dengan model discovery learningtelah terlatih menemukan konsep baru untuk menyelesaikan masalah. Penelitian yang dilaksanakan oleh (Sulistyowati, 2012) juga menyatakan bahwa penerapan model pembelajaran discovery learningdapat meningkatkan kemampuan pemecahan masalah. Melalui pembelajaran discovery learning, siswa akan merasakan pembelajaran lebih bermakna, hal ini disebabkan karena siswa terlibat langsung dalam proses pembelajaran. Siswa mengeksplorasi pengetahuannya dan belajar secara mandiri. Siswa juga terlatih untuk menyelesaikan masalah yang terjadi dan memecahkan tugas yang diberikan. Sehingga pengetahuan yang siswa dapatkan akan bertahan lebih lama. Dengan begitu siswa akan termotivasi lagi untuk terus belajar, mengeksplorasi pengetahuannya, dan menemukan suatu konsep atau pengetahuan baru lagi. Selain itu, model ini mampu menciptakan suasana kelas yang demokratis, lingkungan yang saling menghormati, memberi kesempatan pada siswa untuk belajar sendiri, berpendapat sendiri, serta berdiskusi mencari jalan keluar dalam menghadapi masalah. Hal ini dapat mengembangkan kemampuan berpikir siswa serta menumbuhkan kepercayaan pada diri sendiri yang kuat yang berdampak pada hasil belajar yang lebih baik daripada hasil belajar dengan model pembelajaran konvensional.

\section{KESIMPULAN DAN SARAN}

Kesimpulan dari penelitian ini adalah (1) hasil belajar siswa kelas XI semester genap pada materi pokok 
fluida dinamis dengan menggunakan model pembelajaran discovery learning nilai rata - ratanya sebesar 78,33. Nilai ketuntasan minimal pelajaran fisika di SMA Negeri 1 Stabat adalah 75 ,0berarti nilai rata rata hasil belajar siswa tergolong tuntas. (2) hasil belajar siswa kelas XI semester genappada materi pokok fluida dinamis dengan menggunakan model pembelajaran konvensional nilai rata - ratanya sebesar 74,17. Nilai ketuntasan minimal pelajaran fisika di SMA Negeri 1 Stabat adalah 75 ,0berarti nilai rata - rata hasil belajar siswa tergolong belum tuntas.(3) berdasarkan hasil perhitungan uji $\mathrm{t}$ diperoleh bahwa $t_{\text {hitung }}>t_{\text {tabel }}(2,26>1,988)$. Hal ini disebabkan karena adanya perbedaan hasil belajar siswa di kelas eksperimen dan kelas kontrol. Berarti, model pembelajaran discovery learning berpengaruh terhadap hasil belajar yang diperoleh siswa. Artinya $\mathrm{H}_{\mathrm{a}}$ diterima yakni hasil belajar siswa menggunakan model pembelajaran discovery learning lebih baik daripada hasil belajar siswa dengan menggunakan model pembelajaran konvensional pada materi pokok fluida dinamis kelas XI semester genap di SMA N 1 Stabat T.P 2014/2015.

Berdasarkan penelitian yang telah dilakukan, terdapat beberapa kendala yang dihadapi. Agar kendala - kendala yang terjadi tidak terulang kembali, sebaiknya para peneliti selanjutnya terlebih dahulu memperhatikan kelemahan dan kekurangan yang terdapat dalam penelitian ini. Sehingga kendala, kelemahan, dan kekurangan dalam penelitian ini tidak terulang kembali dan dapat diperbaiki oleh para peneliti selanjutnya. Para peneliti yang akan melakukan penelitian dengan menggunakan model pembelajaran yang sama yaitu model pembelajaran discovery learning, sebaiknya melaksanakan proses pembelajaran sesuai dengan sintaks (langkah - langkah) model pembelajaran discovery learning dan menyesuaikan waktu dengan keadaan pada proses pembelajaran. Sehingga proses pembelajaran dengan menggunakan model pembelajaran discovery learning dapat berjalan dengan efisien dan memberikan hasil yang lebih baik lagi dari penelitian yang telah dilakukan.

\section{DAFTAR PUSTAKA}

Herdian. 2010. Pengaruh Model Discovery Terhadap Kemampuan Analogi Dan Generalisasi Matematis Siswa SMP. Tesis S2. Program Pascasarjana UNS, Surakarta.

Hosnan. 2014. Pendekatan Saintifik Dan Kontekstual Dalam Pembelajaran Abad 21 Kunci Sukses Implementasi Kurikulum 2013. Ghalia Indonesia, Bogor.

Jacobsen, D.A., Eggen, P., Kauchak, D. 2009.Methods for Teaching. Terj. Sri Mulyantini Soetjipto.Pustaka Pelajar, Yogyakarta.

Putrayasa, I.M.,Syahruddin, H., Margunayasa, I.G. 2014. Pengaruh Model Pembelajaran Discovery Learning Dan Minat Belajar Terhadap Hasil Belajar IPA Siswa. Jurnal Mimbar PGSD Universitas Pendidikan Ganesha. 2: 1

Rahman, R., Samsul M. 2014.Pengaruh Penggunaan 
Metode Discovery terhadap Kemampuan Analogi Matematis Siswa SMK AlIkhlas Pamaciran Kabupaten Ciamis Jawa Barat.Jurnal Ilmiah Program Studi Matematika STKIP Bandung.3(1):33-55.

Slavin, R E. 2011.Psikologi Pendidikan Teori dan Praktik. Indeks, Jakarta.

Sulistyowati, N., Anthonius T., Woro S. 2012.Efektivitas Model Pembelajaran Guided Discovery Learning Terhadap Kemampuan Pemecahan Masalah Kimia. Chemistry in Education.2(1): 49-55. 